\title{
Front Matter: Volume 10517
}

, "Front Matter: Volume 10517," Proc. SPIE 10517, Real-time Measurements, Rogue Phenomena, and Single-Shot Applications III, 1051701 (3 May 2018); doi: $10.1117 / 12.2322772$

SPIE. Event: SPIE LASE, 2018, San Francisco, California, United States 


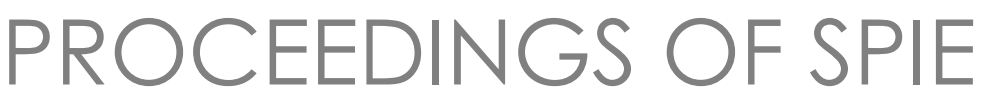

\title{
Real-time Measurements, Rogue Phenomena, and Single-Shot Applications III
}

\author{
Bahram Jalali \\ Daniel R. Solli \\ Günter Steinmeyer \\ Editors
}

29-30 January 2018

San Francisco, California, United States

Sponsored and Published by

SPIE 
The papers in this volume were part of the technical conference cited on the cover and title page. Papers were selected and subject to review by the editors and conference program committee. Some conference presentations may not be available for publication. Additional papers and presentation recordings may be available online in the SPIE Digital Library at SPIEDigitalLibrary.org.

The papers reflect the work and thoughts of the authors and are published herein as submitted. The publisher is not responsible for the validity of the information or for any outcomes resulting from reliance thereon.

Please use the following format to cite material from these proceedings:

Author(s), "Title of Paper," in Real-time Measurements, Rogue Phenomena, and Single-Shot Applications III, edited by Bahram Jalali, Daniel R. Solli, Günter Steinmeyer, Proceedings of SPIE Vol. 10517 (SPIE, Bellingham, WA, 2018) Seven-digit Article CID Number.

ISSN: 0277-786X

ISSN: 1996-756X (electronic)

ISBN: 9781510615199

ISBN: 9781510615205 (electronic)

Published by

SPIE

P.O. Box 10, Bellingham, Washington 98227-0010 USA

Telephone +1 3606763290 (Pacific Time) · Fax +1360647 1445

SPIE.org

Copyright @ 2018, Society of Photo-Optical Instrumentation Engineers.

Copying of material in this book for internal or personal use, or for the internal or personal use of specific clients, beyond the fair use provisions granted by the U.S. Copyright Law is authorized by SPIE subject to payment of copying fees. The Transactional Reporting Service base fee for this volume is $\$ 18.00$ per article (or portion thereof), which should be paid directly to the Copyright Clearance Center (CCC), 222 Rosewood Drive, Danvers, MA 01923. Payment may also be made electronically through CCC Online at copyright.com. Other copying for republication, resale, advertising or promotion, or any form of systematic or multiple reproduction of any material in this book is prohibited except with permission in writing from the publisher. The CCC fee code is 0277 $786 \mathrm{X} / 18 / \$ 18.00$.

Printed in the United States of America.

Publication of record for individual papers is online in the SPIE Digital Library.

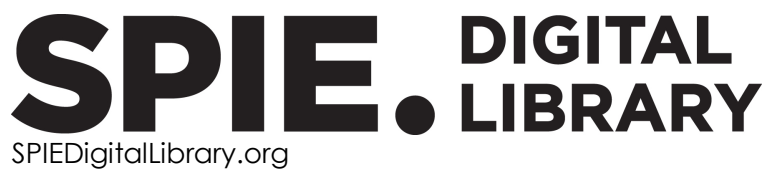

Paper Numbering: Proceedings of SPIE follow an e-First publication model. A unique citation identifier (CID) number is assigned to each article at the time of publication. Utilization of CIDs allows articles to be fully citable as soon as they are published online, and connects the same identifier to all online and print versions of the publication. SPIE uses a seven-digit CID article numbering system structured as follows:

- The first five digits correspond to the SPIE volume number.

- The last two digits indicate publication order within the volume using a Base 36 numbering system employing both numerals and letters. These two-number sets start with $00,01,02,03,04$, 05, 06, 07, 08, 09, OA, OB ... 0Z, followed by 10-1Z, 20-2Z, etc. The CID Number appears on each page of the manuscript. 


\title{
Contents
}

\author{
$\checkmark \quad$ Authors \\ vii Conference Committee
}

\section{LASER TRANSIENTS AND NONREPETITIVE PHENOMENA}

1051704 The picosecond structure of ultra-fast rogue waves (Invited Paper) [10517-3]

REAL-TIME TECHNIQUES

1051709 Time stretch dispersive Fourier transform based single-shot pulse-by-pulse spectrum measurement using a pulse-repetition-frequency-variable gain-switched laser (Invited Paper) [10517-8]

10517 OA Fast wide-field Raman spectroscopic imaging based on multi-channel narrow-band imaging and Wiener estimation (Invited Paper) [10517-9]

$10517 \mathrm{OB}$ Accuracy and precision in broadband laser ranging [10517-10]

NONLINEAR DYNAMICS AND MEASUREMENTS I

10517 OE Optical Kerr spatiotemporal dark extreme waves (Invited Paper) [10517-13]

10517 OF Non-destructive phase and intensity distributed measurements of the nonlinear stage of modulation instability in optical fibers (Invited Paper) [10517-14]

$10517 \mathrm{OH}$ Megahertz measurement rate wavemeter with sub-picometer resolution using second harmonic generation [10517-16]

NONLINEAR DYNAMICS AND MEASUREMENTS II

10517 OM Pulse characterization by cascading nonlinearity inside a spectrometer (CaNIS) [10517-21]

10517 ON A real-time multi-gases detection and concentration measurements based on timedivision multiplexed-lasers [10517-22]

\section{POSTER SESSION}

10517 OP Laser goniometer used for remote measurement of angular position and movement for metrology [10517-24] 
Proc. of SPIE Vol. 10517 1051701-4

Downloaded From: https://www.spiedigitallibrary.org/conference-proceedings-of-spie on 26 Apr 2023 Terms of Use: https://www.spiedigitallibrary.org/terms-of-use 


\section{Author Index}

Numbers in the index correspond to the last two digits of the six-digit citation identifier (CID) article numbering system used in Proceedings of SPIE. The first four digits reflect the volume number. Base 36 numbering is employed for the last two digits and indicates the order of articles within the volume. Numbers start with 00, 01, 02, 03, 04, 05, 06, 07, 08, 09, 0A, 0B...0Z, followed by 10-1Z, 20-2Z, etc.

Asghari, Mohammad, 09

Baronio, Fabio, OE

Bennett, Corey, OB

Chen, Shuo, OA

Christensen, Mathias, $\mathrm{OH}$

Conforti, Matteo, OF

Copie, François, OF

Diels, Jean-Claude, OM

Duadi, Hamootal, 04

Eno, N. A., OP

Filatov, YU. V., OP

Fridman, Moti, 04

Furukawa, Hideaki, 09

Hansen, Anders K., $\mathrm{OH}$

Horstman, Luke, OM

Hsu, Ning, OM

Jalali, Bahram, 09

Jensen, Ole B., $\mathrm{OH}$

Jimenez, Alvaro, ON

Klein, Avi, 04

Kobayashi, Tetsuya, 09

Kodama, Yuji, OE

Kolpakov, Stanislav A., 04

Kudlinski, Alexandre, OF

Lib, Ohad, 04

Liu, Quan, OA

Makino, Takeshi, 09

Man, Wai Sing, 09

Masri, Gilad, 04

Milde, Tobias, ON

Mussot, Arnaud, OF

Naveau, Corentin, OF

Noordegraaf, Danny, $\mathrm{OH}$

Pavlov, P. A., OP

Perlaki, Clint, OA

Perry, Daniel, OB

Rhodes, Michelle, OB

Sacher, Joachim, ON

Shahal, Shir, 04

Skovgaard, Peter M. W., $\mathrm{OH}$

Steinberg, Hadar, 04

Sulimani, Kfir, $\mathrm{O4}$

Szriftgiser, Pascal, OF

Tatenguem Fankem, Hervé, ON

Trillo, Stefano, OF

Trinh, Paul, 09

Tsang, Kwong Shing, 09
Wabnitz, Stefan, OE

Wada, Naoya, 09

Wang, Xiaomin, 09

Yazdandoust, Fatemeh, ON

Yoo, Yeu Cian, OA 
Proc. of SPIE Vol. 10517 1051701-6

Downloaded From: https://www.spiedigitallibrary.org/conference-proceedings-of-spie on 26 Apr 2023 Terms of Use: https://www.spiedigitallibrary.org/terms-of-use 


\section{Conference Committee}

Symposium Chairs

Koji Sugioka, RIKEN (Japan)

Reinhart Poprawe, Fraunhofer-Institut für Lasertechnik (Germany)

Symposium Co-Chairs

Xianfan Xu, Purdue University (United States)

Beat Nevenschwander, Berner Fachhochschule Technik und Informatik (Switzerland)

Program Track Chairs

Vladimir Ilchenko, GM Cruise LLC (United States)

Paul O. Leisher, Rose-Hulman Institute of Technology (United States)

Conference Chairs

Bahram Jalali, University of California, Los Angeles (United States)

Daniel R. Solli, University of California, Los Angeles (United States) and Georg-August-Universität Göttingen (Germany)

Günter Steinmeyer, Max Born Institute for Nonlinear Optics and Short Pulse Spectroscopy (Germany)

Conference Program Committee

Nail Akhmediev, The Australian National University (Australia)

Mohammad H. Asghari, University of California, Los Angeles (United States)

Serge Bielawski, Université des Sciences et Technologies de Lille (France)

John M. Dudley, FEMTO-ST, Université de Franche-Comté, CNRS (France)

Moti Fridman, Bar-llan University (Israel)

Hideaki Furukawa, National Institute of Information and Communications Technology (Japan)

Goëry Genty, Tampere University of Technology (Finland)

Georg Herink, Georg-August-Universität Göttingen (Germany)

Takuro Ideguchi, The University of Tokyo (Japan)

Dario Polli, Politecnico di Milano (Italy)

Claus Ropers, Georg-August-Universität Göttingen (Germany) 
Pierre Suret, Laboratoire de Physique des Lasers, Atomes et Molécules (France)

Masayuki Suzuki, Aichi Medical University (Japan)

Majid Taki, Université des Sciences et Technologies de Lille (France)

Paul D. Trinh, Time Photonics, Inc. (United States)

\section{Session Chairs}

1 Laser Transients and Nonrepetitive Phenomena

Daniel R. Solli, University of California, Los Angeles (United States) and Georg-August-Universität Göttingen (Germany)

2 Real-time Techniques

Günter Steinmeyer, Max Born Institute for Nonlinear Optics and Short Pulse Spectroscopy (Germany)

3 Nonlinear Dynamics and Measurements I

Bahram Jalali, University of California, Los Angeles (United States)

4 Nonlinear Dynamics and Measurements II

Serge Bielawski, Université des Sciences et Technologies de Lille (France) 